\title{
Psychotherapy in Hospitals in Brazil and Some Contributions from Psychoanalysis: A Historical Study
}

\author{
Sonia Alberti ${ }^{1}$, Roseane Freitas Nicolau ${ }^{2}$, Maria Lívia Tourinho Moretto $^{3}$ \\ ${ }^{1}$ Instituto de Psicologia of the Universidade do Estado do Rio de Janeiro, CNPq, Pedro Ernesto University \\ Hospital, Rio de Janeiro, Brazil \\ ${ }^{2}$ Faculdade de Psicologia of the Universidade Federal do Pará, Belém, Brazil. \\ ${ }^{3}$ Instituto de Psicologia of the Universidade de São Paulo, Journal of the Brazilian Society of Hospital \\ Psychology, São Paulo, Brazil \\ Email: sonialberti@gmail.com,rf-nicolau@uol.com.br, liviamoretto@usp.br
}

Received 29 April 2016; accepted 26 June 2016; published 30 June 2016

Copyright (C) 2016 by authors and Scientific Research Publishing Inc.

This work is licensed under the Creative Commons Attribution International License (CC BY).

http://creativecommons.org/licenses/by/4.0/

(c) (i) Open Access

\section{Abstract}

Psychotherapeutic practice in hospitals in Brazil started in the 1950s even before the profession of psychologist in the country was formalized, and has been building a fairly rich history because it is differentiated according to the development of the practice over the decades as a function of the various clinical methods associated with it, as a consequence of the policies and/or different theoretical orientations that have underpinned it. Twenty years after this practice began, during the 1970s, the field of mental health was configured as a major center of absorption of psychologists in an attempt to change the prevailing medical model. It is at that time that we can first see the formation of multidisciplinary teams linked to psychotherapy treatments. When we examine the relationship between the advancement of the practice and its theoretical foundations, in a field where political orientations toward the practice carried no less weight, we realize that this entire movement has led to important developments in the history of psychology in general. In order to specify what clinical practice in hospitals has contributed to psychology in general, it is necessary to follow its guidelines over the decades, where we can confirm that a certain prevalence of psychoanalysis has been and is being established. To the extent that it is characterized as a discourse directed at the subject, it is fundamental that it allows for situating the work in the hospital in an exchange with the medical field in such a way that each field may sustain its own particularities, respect their differences, and contribute, each in their own way, toward the advancement of clinical work. From the 1950s through today, clinical practice highlights a concern with asserting subjectivity in hospitals where the contributions of some psychoanalytical developments to different forms of psychotherapy have not been lacking. 


\section{Keywords}

\section{Clinical Psychology, Psychotherapy, Hospital, Psychoanalysis}

\section{Introduction}

The history of Psychotherapy in Hospitals is associated with the history of Hospital Psychology itself, which had its beginning at the end of the 19th century, in Massachusetts, in the United States, when the first multidisciplinary team including a psychologist was formed at McLean Hospital [1].

The general term for Psychotherapy is used to identify various forms of relations between therapists and their patients and families, aiming to stand by patients who need to work through their problems. Studies have found individual psychotherapy to be effective at improving symptoms not only in a wide array of mental illnessesdepression, anxiety, post-traumatic stress disorders, among others-making it both a popular and versatile treatment, but it can also be used for families, couples or groups helping to improve the relationship between individuals as well as permitting them to deal with each other under less stress and anxiety. It can also be used in the field of institutional practices, when the psychologist or the psychiatrist or other related field therapists have to take into account the presence of multiple factors which do have holistic consequences on the treatment of a patient, for example, the relation with healthcare providers in a hospital. The center of each session of psychotherapy is the caring relationship between a mental health professional and a patient or those multiple factors, varying according to a current psychological research study, to the mental health professionals' theoretical orientation, or to what works best for each situation when levels of anxiety are already high and can add to the problems of the weakened state of the patient. The psychoanalytic theoretical orientation has many different ways to work, and we will see how it became more important over the years in Brazilian hospitals. Psychoanalysis stands at the origin of all the major developments in psychotherapy over the past hundred years and is a thorough and rigorous way to work in clinical settings and practice and thus is a solid basis for work in the field of mental health. In the outpatient setting, it is normally the one-to-one relationship which is paramount, where transference comes naturally; inpatient settings, however, with their "web of multipersonal relations, offers many different lines of therapeutic interaction" ([2], p.105) and face-to-face is the most common mode. "Patients are aware of the therapist's position and role within the institution, i.e. there is a social context to therapeutic interaction" ([2], p.106). It is thus a form of teamwork in which patients may also work through their problems. After Tasca et al. [3], the gap between practice and research in psychotherapy is still quite large, and there should be a greater collaboration between psychotherapists and other professionals. It is this gap which drives us to try to verify, first historically, how the practice became so common in Brazilian hospitals.

In Brazil, groundbreaking work bringing the psychologist into the Hospital was implemented by Mathilde Neder at the Clinics Hospital of the University of São Paulo School of Medicine [4]. Honored by the 2005 edition of the journal Psicologia: Ciência e Profissão (Psychology: Science and Profession) Mathilde Neder [5] practiced brief psychotherapy, family psychotherapy and psychosomatic psychotherapy, collaborating, from 1952 to 1954 with the Orthopedic and Traumatology Clinic of São Paulo ${ }^{1}$, psychologically following children who underwent spinal surgeries and their families. From then on, Hospital Psychology has been a field of fruitful work in Brazil, as much in terms of care as in terms of research and teaching.

At the hospital, a setting is marked by the presence of suffering, the primary challenges of psychologists have run through both the clinical aspects of their work-the modes of clinical care-as well as the institutional aspects of their work: the inclusion of psychologists in healthcare teams and support for their work in the multidisciplinary environment, based on the differing discourses inherent to the work of the teams [6].

At the hospital, clearly, clinical care is the primary activity of all the professionals who make up the healthcare team, each one in their specialty and, preferably, all of them are attentive to the integration of their actions, seeking the progressive care of the patient. What characterizes clinical care at Healthcare Institutions is the fact that it takes place, predominantly, through actions undertaken by a multidisciplinary team oriented toward the treatment of well-established medical conditions or illnesses.

The presence of psychology in hospital institutions has led healthcare workers to construct different modes of

${ }^{1}$ Currently the Institute for Orthopedics and Traumatology. 
action, in accordance with existing policies and/or the points of view of the various theoretical orientations. On one hand, adaptive psychological practices and routine protocols are developed, aiming to meet the needs, especially medical needs, when they realize that patients and/or family members are having difficulty adapting to the conditions imposed by organic diseases or illnesses, needing to be seen by a psychologist to deal with anguish identified at the time of hospitalization or if the medical orders and prescriptions are not being followed.

We may assume that, according to this orientation, psychotherapy assistance and follow-up would serve as support for the work of the physician in the hospital, where the psychologist forms part of the team just as the other healthcare professionals, nurses, social workers, nutritionists, among others, who all work with the same goal of seeking what is best for the patient according to the medical discourse.

On the other hand, clinically listening to patients in terms of different modes and comprehension can lead to a practice that differs slightly from the first: not as much following the medical discourse, but not for that reason any less concerned with seeking what is the best for the patient. How? Taking into account the possibility of the patient finding what they judge to be the best for them self. Clinical work in Psychology along the lines of this other orientation no longer seeks to adapt itself to the medical discourse but rather, asserts the presence of a subject there where the hospital discourse sees, first and foremost, a patient—in a place where they must suffer passively the multiple actions of a discourse that often believes it knows better than the actual patient what is the best for them, a subject considered to be the very actor of their treatment, not denying their suffering but attributing to the patient an activeness and a responsibility which in and of itself creates change. According to what we have been able to find in the history of the presence of psychotherapy in hospitals in Brazil, it is not unusual for this second way of being present in the hospitals to lead the therapists to a position which is not always consistent with the medical discourse, and which sometimes directly contradicts it, to the extent that situations often arise in which what the doctor judges to be the best for the patient is not necessarily what the patient judges to be best for themselves. Thus the psychotherapist continues to introduce a function into the hospital: that of supporting the subject, regardless of the possibility that will eventually lead to conflicts of orientation. Clearly these modalities did not begin to function in this way immediately; we will try to flesh out their development.

The history of Psychology itself is the history of the continuous search for the improvement of tools, techniques and methods of study oriented toward reaching a precision and objectivity based on the scientific method. This is what underpins the procedures and policies of healthcare, which over time has been prioritizing procedures and scientific techniques applied en masse, at the same time in which a space is opened for other approaches springing from initiatives of clinicians who choose the possibility of valuing each subject in their own singularity and difference. In terms of the techniques of psychotherapy, what is observed throughout their history in hospital services is the unfolding of two lines of methodology: the first one seeks an approach which is based on the idea that it is possible to attend to a number of people at the same time, so that group techniques are prioritized, while the second seeks to provide care which prioritizes each person, in their own singularity.

In the mid-1990s, Ana Cristina Figueiredo developed a project to examine psychological services at hospitals in Rio de Janeiro, which led to the publication of her book Massive Misunderstandings and Imperfect Care [7], a reference for everyone who was interested in the history of these issues. What she unveils in her book is exactly what the title communicates: the care is imperfect, there are huge misunderstandings and often significant theoretical imperfection orienting practices, but at all times there is a great willingness to value psychological care in hospitals.

Today there is a Brazilian Society of Hospital Psychology, founded, coincidentally, in the same year as the publication of Figueiredo's book, a non-profit society, whose objective is strictly scientific, emphasizing scientific publication, carrying out congresses and incentivizing research, aiming to assemble clinical psychologists who work in hospitals. Currently, this society supports a Journal and maintains a frequency of biannual congresses, addressing the topic of the clinical practice of psychology in hospitals.

\section{The First Decades}

According to [8], the first work of psychology in hospitals in Brazil occurred in the mid-1950s, but only in the 1960s did they begin to seek a theoretical foundation for the practice, which was based merely on an "exercise describing tasks" (Chiattone, 2000, apud [9]), demonstrating the "scarcity of theoretical and methodological bases in the general academic training and consequently, the need to implement specialized training” [9]. It is interesting to note that by the end of the 1960s in Brazil, the practice of psychotherapy in hospitals had grown, 
both in the context of medicine and in the context of psychology. In the first context, this practice was directly coupled with a medical discipline, called psychosomatics, and in the second, initially under the auspices of what was discussed and practiced in that discipline, slowly but surely an activity emerged that became more and more independent.

According to Eksterman [10]—associated with a group of doctors who were studying psychosomatics—-the medical psychology approach made possible the adoption in the hospital of what was understood in the 1970s as a holistic therapeutic ideal, which was to see the patient as a whole and not merely as a sick person whose organs or organism wasn't working right. This adoption was of great importance to psychology because it began to open the doors of the hospitals to the work of psychologists who were sometimes invited to participate in the activities of the discipline, specifically in weekly meetings with the doctors.

It is not without relevance that the doctors that introduced that discipline into medical curricula had psychoanalytical training-according to Eksterman it was with Freud that the "intimate link between the mind and the body in the sense of producing pleasure, suffering, injury or sickness" [10] was established in the clinical field. This determined, to a great extent, what became known as the order of a psychotherapy approach based on psychoanalysis in hospitals, seeking, at the same time, a theoretical and practical consistency beyond the simple description of tasks.

In 1962, Federal Law no. 4119 recognized Psychology as a profession in Brazil, opening the possibility for the clinical psychologist to be included in Healthcare Institutions a decade later: it began to be possible to hire psychologists in hospitals. In the early 1970s, some psychologists were seeing pregnant women in maternity wards, and later moved on to other pediatric services. According to Alberti \& Almeida [11], Professors Maria Tereza Maldonado and Elisabeth Ribeiro were the only references in Rio de Janeiro for a hospital practice in the 1970s. Caplan, G. [12] was studied, with the levels of primary, secondary and tertiary care, and a theory was sought that could serve as a basis for the logic of the association with psychologists for clinical work in the institution. Texts were read such as those of Loreau [13] about institutional analysis, published in France; Caplan, which we mentioned - from the United States; Balint [14] and his group technique-from England, or even texts on group psychotherapy by Moreno [15]; humanized care for children with serious psychic impairment, with Bettelheim [16]; the contributions of the French women Maud Mannoni [17]—on the care of children in institutions - and Ginette Raimbault [18] about the child and death. They were all texts that made some reference to issues involved in hospital practice, from group therapy, alternative forms of psychiatric hospitalization, or even the issue of the subject facing death, texts read, discussed and evoked avidly each time one of those issues would come up. Simultaneously, they studied the history of the clinic, of the institution, of the relationship between the branches of government, of psychiatry, of psychology, especially the texts of Michel Foucault [19] and his archeology of the medical clinic; Didier Deleule [20] and the relationship between philosophy and psychology; Georges Canguilhem [21] and the critique of the medical taxonomy, and the Brazilians: Roberto Machado et al. [22], Jurandir Freire Costa [23], among others, authors with whom it was still possible to discuss issues personally, or even texts smuggled from France that described the Chinese Cultural Revolution. Psychoanalysis was also studied, that is, Freud's texts, searching for a theoretical foundation for psychotherapy and clinical psychology in the hospital setting. Keeping in mind the political situation of the country at the time, i.e. the military dictatorship, "They were debates and discussions often carried out behind closed doors, the books often hidden away, since there was fear that hard fingers [snitches] would interpret them as a reason to hand over 'those students' to the DOI-CODI ${ }^{2,}$ [11]. The primary debate aimed to clarify a great misconception: on one hand psychological practices were interpreted as individualistic by a rising political left, in particular, psychoanalysis was interpreted in this way, practices that would aim toward brainwashing away all sociological perceptions. On the other hand, everyone who delved into Freud's texts became concerned specifically with issues of censorship, repression and social issues deeply dialectized in his work, also leading to a questioning of the current political and economic order.

\section{Psychotherapy Practices in Hospitals: A Political Issue}

It is a fact that the clinical practice of psychology in hospitals already began with an institutional orientation, that is, when it began it was taking into account the possible linkage between psychological theories and their connection to institutional work. Some authors identify there the difference between the practice in hospitals and

\footnotetext{
${ }^{2}$ The Brazilian political police at the time of the military dictatorship (1964-1985).
} 
psychotherapies generally: regardless of those modalities, "it remains clear that seeing the patient in the hospital setting does not reproduce the dyad found in situations of traditional psychotherapy, characterized by maintaining a reserved space and as much as possible a consistent one” [24]. Whether it be in relation to the hospital setting, whether it be in relation to the school, to the law or even to the family, "the proposal was not to limit ourselves to the four walls of an office” [11], not without also aiming for the possibility of carrying out the clinic based on theoretical frameworks in the institutions.

Yet it was the important changes which took place in the Brazilian political scene toward the end of those 1970s that culminated in the complete breakdown of the hegemonic and hospital-centered medical model [25], giving rise to changes in the context of public healthcare policies, allowing other professionals in the door. The concept of health was changing: it was no longer merely the absence of illness, but the prophylactic notion itself was included in it, leading a significant number of psychological professionals to converge on the Public Healthcare field, thus expanding their field of activity [26]. Hence, a disconnect was created between the language associated with the medical discourse that "creates a linguistic barrier that stops the patient from understanding what is happening with their own body [...] seen through machines, measured, weighed, x-rayed, eliminating human contact more and more” [27] and the situation established by the presence of clinical psychology in hospitals. Based on the medical discourse the patient never or rarely is questioned about their desires or story, as they are subjected to the norm by which being "sick, they seek a doctor; sick over love, a candomblé holy father or a friend; having sinned, a priest” ([28], p. 31), and from all of the above they receive guidance dictated by knowledge that is not necessarily their own. To the contrary, followed by the psychotherapy framework, the treatment is dictated by that which is brought by the patient themself, who is not so patient by then, but rather more active than passive, as we could establish above. At the same time, it is always good to remember that beyond what is implied by said framework sustaining a very specific work together with the patient, by joining a healthcare team the psychologist, "must favor the interdisciplinary functioning, facilitating, when necessary, communication between its members" [27].

It is possible "to say that starting at the end of the 1970s, the field of mental health was configured as a great pole absorbing psychologists, in an attempt to move the medical model and to form multidisciplinary teams” ([26], p. 58). A very meaningful example of this change in the practice of the psychologist in hospitals was seen based on a very common observation where the doctors, not wanting to face the anguish of their patients and family members, would assign the task of giving news of death or diagnoses with a poor prognosis to the psychologists. Such practices were hotly debated and are virtually barred from happening in hospitals currently. Psychologists can even help the doctors to deal with the difficulties of the daily routine of the clinic, but may never assume a task whose responsibility rests on the doctor.

With the implementation of guidelines that prioritize group-based techniques, the guidelines have gained ground in comparison with the ability to listen for singularities. The practices of professionals, generally based on "ethics of the good," were built on the ideal of healthcare for all, in which the suffering of the subject is cared for through the application of "healthcare technologies," which include procedures with rules and norms established in the name of the success of the treatments. Indeed, the ethic of care seeks to be universal and applicable to everyone indistinctly. It operates with a constituted knowledge, of the order of scientific knowledge, organized and accumulated in order to intervene upon the patient. In spite of such excellent intentions, at the time when one considers intervening upon the patient based on prior organized knowledge, often constructed as a model to be followed, the clinic, in the most basic sense of the word, becomes threatened.

Even so, with the advancement of the clinic in the hospital, the psychologist has become an integral part of the workforce of healthcare teams, developing an essential role concerning the activities of comprehensive assistance to the user of the System, to such an extent that, in 2010, the Federal Council of Psychology, through the CREPOP (Center of Technical Reference in Psychology and Public Policies) affirmed that the government is the largest employer (76.6\%) of this professional category in hospitals throughout the country (CREPOP, 2010).

With the development of the field called Health Psychology in some Latin American countries, the Latin American Association of Health Psychology (ALAPSA) emerged in 2003 [9], following the international movement which had previously created the division of Health Psychology (Division 38) in the American Psychological Association (APA) and in 1986, the European Health Psychology Society (EHPS). A number of authors emphasize the link between clinic and politics in the rise of the psychological clinic in hospitals [11] [29]-[31] keeping in mind the necessary "resistance to the dictatorial regime in which [Brazil] was enveloped" ([26], p. 59), where movements were created basically made up of progressive intellectuals, with the goal of 
constituting "anti-hegemonic knowledge, criticizing the dominant healthcare model and producing a reform in the policies and practices of healthcare that prevailed in Brazil, so as to make possible the real availability of healthcare to the entire population" ([26], p. 59).

We can say that the link between politics and the movement to insert psychotherapy practices into hospitals was born of non-conformity during the so-called "years of lead" (dark years) in Brazil, where what prevailed was censorship, intolerance for differences, torture and the reactionary ideology of the military regime. In a lecture given in 1988, Martín-Baró cited something that happened in Rio de Janeiro which explains the dimension of those "years": "the government turned to a military operation and to sending a tank against a psychiatric hospital to remove the team of staff members who intended to establish a mental healthcare plan different from the officially dictated one" apud [32]. So the linkage between the clinic and politics implied, from its birth, an ethical position. And it is the link between the ethics and the politics that has historically supported, as a rule, the bases of psychotherapy work in hospitals in Brazil.

\section{Notes about Psychotherapy Treatments during the 1970s}

As Tonetto \& Gomes [33] write, the "psychotherapeutic treatment of hospitalized patients and their family members is usually carried out individually", which does not exclude other modalities which range from referrals to bedside therapy, aiming "to assess the emotional state of the patient; to answer questions about the diagnosis and hospitalization; to soothe anguish and anxieties when facing unfamiliar situations; to work on the mother-baby bond; to work on aspects of sexuality involved in the illness and its treatment; to prepare for surgery; to guarantee compliance with treatment; to assist with adaptation to the living condition imposed by the illness; to guide parents about the best ways to inform children of the hospitalization or death of a family member, and to facilitate encounters with situations of mourning and death” ([33], p. 286).

Now we will turn to some indications taken from the account of two experiences which occurred during the 1970s:

a) Work carried out at the Instituto de Puericultura e Pediatria Martagão Gesteira (IPPMG, Martagão Gesteira Institute of Child Care and Pediatrics) of the Federal University of Rio de Janeiro, in 1977 and 1978: the Balint group and ambulatory care.

"At the IPPMG [...] there was a hired psychologist as well as a physician-psychoanalyst, who held a Balint Group every Monday. Those of us who were psychologists without a contract were provided to attend these groups and to attend to children referred to the psychology service” [11]. The Balint Group was led by the doctors: the residents presented a clinical case and the physician-psychoanalyst played the role of the patient and their symptoms, very often considered psychosomatic. Since the physician-psychoanalyst we are talking about was a member of the IPA ${ }^{3}$, having completed his psychoanalytic training there in the 1960s, the aim of the interpretations was primarily to find meanings that would help to understand the suffering of the patient. In addition, the physician-psychoanalyst would often interpret reactions to transferences of the medical residents, interpretations that enriched the clinical cases even more meaningfully. "It was interesting to see the prestige that this physician-psychoanalyst enjoyed at the hospital, despite never having treated a single clinical case there and, therefore, never having performed a single diagnosis based on transference with the diagnosed patient” [11].

Such success could only be the consequence of a great repressed demand on the part of the doctors of the hospital who, facing the daily reality of the clinic, needed to be able to talk about it in any way possible. The transference we are talking about was that of the doctors in relation to the physician-psychoanalyst; it was this transference that was underlying the work and it was that which allowed psychotherapy in the hospital to be tolerated, that is, the transference of the medical corps with this physician-psychoanalyst was underlying, in a secondary way, the work of the psychotherapists with the patients in the hospital. The patients that they saw were not referred by any multidisciplinary team, but rather by schools and/or brought in by parents who found out about the psychology service. "They were two completely separate practices: one, the work with the doctors, carried out by a physician-psychoanalyst; the other, the work with the patients of the IPPMG" [11], children with learning difficulties, a history of aggressiveness and maladjustment to their environment, "referred to psychologists for ambulatory treatment where we kept an appointment schedule that also included our regular patients-those we saw for psychotherapy” [11].

In Brazil at the time one did not join the IPA for training if one was not a doctor, or otherwise, one had to sign

${ }^{3}$ International Psychoanalytic Association, founded by Sigmund Freud and still operating today, at an international level. 
a document stating that the psychoanalytic training candidate would agree to always see patients under the control of a colleague who was a physician, even after completing their training. Therefore, it was also the case that in the hospital a psychologist could not carry out treatment based on psychoanalysis. Not only this, but it was explicitly impossible for this to occur. ${ }^{4}$

To justify "psychotherapy with an analytic basis," as those kinds of treatments were called then, these psychotherapists sought outside supervision and worked on clinical cases by seeing patients in a consulting office within the hospital.

A very different experience was that of the Hospital dos Servidores do Estado do Rio de Janeiro (the Hospital of the Public Servants of the State of Rio de Janeiro). Starting in 1976, psychologists began to be hired there, at first to work in the pediatrics area.

b) The Hospital dos Servidores do Estado do Rio de Janeiro (HSE), in the first period: 1976 to 1983.

In this hospital, Psychology began its work in 1976, at the request of the Chief Physician of the Pediatrics Service, comprised of two Wards. The activities of the psychologists rested on a developmentalist approach, based on a philosophy of care that "addressed the human being in their totality, and the hospital as a place which is able to meet the health and well-being needs of the community." 5 Thus, it was an approach whose goal was to integrate the clinical, social and psychological aspects involved.

Despite the demand for psychologists for Pediatrics, there was no clear idea of what the work of the psychologist would be in the institution, so they kept the practice of responding to medical team requests, with sporadic interventions and always in a very timid fashion, trying to draw attention to the presence there of a subject. "Some tests were also used (Gesell, Bender), in keeping with the request made by the medical team that valued data that could be quantified” [11]. The psychologists attended to all the sectors of Pediatrics-ambulatory, wards and ICU-in their different medical specializations.

Since the psychologists came to work at the hospital through different employer-employee relationships and since the psychologists based their work on different theoretical frameworks, there were difficulties with the interconnectedness of the team. The greatest problem, however, "was the lack of a solid theoretical approach that, when working hand in hand with the clinic, could serve as a foundation for that work which involved everything from our patient to so many other discourses and subjects which were found throughout the hospital” [11].

For example, the term "child" appeared in the Pediatrics Service, but linked to the discourse of science and the discourse of pedagogy, which is, coupled with education, establishing treatment routines in a vague attempt to provide for the well-being of the patient.

Despite the difficulties, the psychologists began to demonstrate where they belonged to be in the institution and that opened doors to new areas of work. Psychology began to participate in the Clinical Sessions of Pediatrics, presenting clinical cases and often participating in clinical sessions for other sectors whenever the case involved psychological treatment. The mark of psychology could even be found in interconsultation work and in weekly meetings with the residents of Pediatrics, where the psychologists discussed with them issues such as: child sexuality, obesity, illness and stress in children, among others.

In contrast, therefore, to the experience of the IPPMG, at the HSE there was not such a distance between the work of doctors and that of psychologists, allowing for a dialogue that influenced the care provided by the multidisciplinary team to the children. Having gained ground, the care was no longer only provided in a group setting, but also was individualized for parents as well as for the hospitalized children. The Nursing team also requested the creation of a group to address internal issues in Pediatrics. This was important because it was in this way that it became possible for the team to discuss their difficulties in dealing with certain children which in the end resulted in requests for psychotherapy.

As a function of the existing demand created not only by therapy provided in Pediatrics but also by therapy requested by other clinics, some psychologists left Pediatrics, where there was an excess of supply and went to other services (orthopedics, maternity). In this case we could confirm how the experience of listening to the cases, that is, how the transmission of work through the clinical case can create a demand for psychologists in other services.

\footnotetext{
${ }^{4}$ The idiosyncrasies of the IPA itself only truly came to light later, with the accusation of Hélio Pellegrino and Eduardo Mascarenhas about the cover-up carried out by the leadership of the IPA of the participation of an analyst in the practice of torture by the military regime, an accusation that was only possible thanks to the work of Helena Bessermann Vianna inside the Brazilian Psychoanalytic Society (Sociedade Brasileira de Psicanálise) [11].

${ }^{5}$ Project of the Psychology Service of the Hospital dos Servidores do Estado, 1983 (Mimeo).
} 
The lack of definition in terms of a theoretical orientation for these experiences during the decade of the 1970s was in contrast to the search for psychoanalytic training undertaken by some of the psychologists who began working in the hospitals. There were those who "practice brief and focused psychotherapy" [33] and those who invested, more and more, in the possibility of linking psychoanalysis with the objectives of clinical work in the hospital.

\section{The Second Period: From Psychology to Psychoanalysis-Based Psychotherapy}

In the decade of the 1980s, this second track was consolidated. In the abovementioned HSE, Psychology was no longer subordinate to Pediatrics and was established as the Psychology Service in 1983, becoming part of the organizational chart of the hospital, as a clinical service, exactly like the medical services. More well-structured, the Psychology Service was opened to the formation of academic internships, together with a required course and supervision. "This led the psychologists of the [Psychology Service] to study more and consequently to think more theoretically about their work” [11]. At the time, some psychoanalytic training institutions already accepted psychologists and it was there that they sought a theoretical grounding that could give direction to their work. Based on this, "A number of attempts were also made along the lines of creating a space within the Psychology Service to discuss the difficulties of seeing patients in a general hospital. Meetings took place to discuss theoretical texts and the clinical session” [11]. Again some political problems imposed themselves, creating movements to block the access to psychologists and, especially, to deal with "so many tasks and requests to respond to, that the most precious part of this work, the clinic with the subject in the hospital" [11] ran the risk of being relegated to a lower priority. "The order of the day was: produce!, without regard to how” [11].

Another service that included psychologists’ right from the beginning of its creation as a service, in 1974 in Rio de Janeiro, was the Adolescent Health Care Center (UCA — today called NESA) at the Pedro Ernesto University Hospital (HUPE), of the Rio de Janeiro State University. In 1980 one psychologist was on staff and, in the same way that was seen with the HSE, at the UCA the Psychology Sector had an overabundance of job requirements and requests and since there was only one psychologist, there were others who worked as trainees or worked as part of fellowships. The requests ran the gamut from attending to internal issues in the multidisciplinary team, to patient groups, even a number of specific programs developed by the multidisciplinary team (group of pregnant women, high-risk, ward, ambulatory, advanced ambulatory, etc.). Each one of these groups wanted a psychologist in charge of attending to specific clinical cases... Since there were no new positions opened, the consequence was a constant instability, on the one hand due to the high turnover of psychologists (trainees or those with fellowships), and on the other hand, due to the very difficulty of the multidisciplinary team in discerning what the job description of the psychologist should be, in light of different strands of psychology. In the absence of a project of their own, the psychologists joined the general projects of the UCA, without knowing neither exactly what was at their disposal in those projects nor how to lead an activity. The lack of experience in research and in academic papers also meant that these professionals, often excellent at assisting others, did not know how to articulate a work project.

As we have already established in the two experiences analyzed from the IPPMG and the HSE, the first two decades of work at the UCA/HUPE demonstrate the difficulty of inserting psychologists into the general hospital and the necessary elaboration of the conditions for work that is possible. But there was a new piece of data in this service: it came to be formed, more and more, by psychologists linked to psychoanalytic institutions.

When Ana Cristina Figueiredo [7] began her thesis project called Massive Misunderstandings and Imperfect Care, the situation in the hospitals led her to three kinds of critique: 1) a critique of the ever renewed medical attempts - particularly on the part of psychiatrists and neurologists - to subsume the field of psychotherapy; 2) a critique of the way in which psychoanalysis was established in hospitals, based on the medical discourse as mentioned above, always seeking more and more sense and interpreting not only patients, but even therapists and what was understood as being of the order of countertransference; 3) a critique of the difficulty in sustaining a practice with the lack of a common theory in a team. Figueiredo perceived that the teams which reached the best results in their therapy and multidisciplinary work were those that claimed to be based on Jacques Lacan's reading of the work of Sigmund Freud, a reading that breaks with the eternal interpretative requirement and, at the same time, takes into account the pair of ethics and politics to take up again, with Freud, the notion that all individual psychology is also a social psychology ([34], p. 104); ([35], p. 73); ([36], p. 38). Figueiredo then raises the hypothesis that there is something in that form of theoretical approach to the clinic that facilitates the 
occurrence of the practice of psychotherapy in hospitals. In reality, a clinic that does not take into account the individual nature and the singularity of each case is basically impossible, even if we know that each case presents aspects that may be identified in common structures. A medical case may even be equivalent to another, but no subject, as such, can be equivalent to another, each one is merely one, unique. This is what leads to the clinic in its most fundamental sense, and that radically involves what was delimited based on the ethics of psychoanalysis. Today listening to the complaint of the patient may surpass the context of the organ or the member of the body. "This does not mean excluding the illness from medical discourse, but including and asserting another form of listening, a keener form, which indeed is inherent to clinical activity, from its beginnings, with Hippocrates" [37].

\section{Psychology in the Hospital and Psychoanalysis}

Beginning in the 1990s, a great portion of the psychotherapy work in general hospitals in Brazil came to rely on this orientation, finding in it the theoretical underpinnings of practice through to this day. No longer psychotherapy with an analytical basis, say the majority of authors researched, but a field with psychoanalysis running through it, with its relationship to the world, to discourses, to the clinic and ethic of its own, defined by Sigmund Freud and Jacques Lacan [7] [38]-[43]. These modifications have also been observed in relation to psychiatric institutions, where "psychoanalytically oriented inpatient treatment settings have developed in a number of pioneering centres around the world" ([44], p. 149), sustained on theoretical foundations "in stark contrast to the institutionalising and antiethical culture present in traditional psychiatric settings” ([44], p. 150).

It is precisely because "medicine has entered its scientific phase" [45], that the presence of psychoanalysis in the hospital is so important today. If we rely on Freud's text [46] on the laic nature of psychoanalysis and in his appendix [47], on the risks that scientific medicine introduces into the survival of the clinic, because it is much more concerned and preoccupied with that which would conform to the discourse of techno-science than with the subject themselves which it should be treating, it is fundamental that the clinical field be defended in the hospital. This defense can be made by what Lacan proposes as the place of psychoanalysis in the world that of guaranteeing a place for what is not possible to know, for the impossible, for that which ruptures the established discourses.

According to the authors we have studied in our research, psychoanalysis understands that the work of the psychologist in hospitals and in healthcare institutions in general is to offer a form of listening to the singularities, providing for the emergence of completely singular desire, involved with suffering and what is impossible to resolve with prior knowledge or even what is constructed by another, other than the subject themselves in their singularity. According to Lacan [48], psychoanalysis contains within it a policy which the psychologist cannot give up: to make psychoanalysis and the subject of desire exist, and not the reduction of them to pre-established models, nor to demands for a cure-which Freud identified as being of the order of a furor sanandi apud [7].

How can one defend this position, which is the clinic, when faced with a policy of massification? The answer that has been given to this impasse is: seeking out the unconscious with the offer of listening to the sick, utilizing to this end the tools already available at the institution. In this way it is possible to link the services of the hospital with the dimension of the psychoanalytic clinic. It is thus that psychoanalysts, resisting such a policy, have managed to maintain a form of listening one on one, in the midst of work involving assistance or sensitizing the patient to comply with treatment practiced by the psychologists, following the convocation made by Lacan that analysts not cede to a policy of massification, but insist on listening one on one [49].

Saving this has been the challenge faced by many analysts who, working against the healthcare policies that involve erasing singularity, try to construct mechanisms of inclusion of the subject themselves. This is a commitment that has advanced not only the field of the institutional psychological clinic, but also psychoanalysis, since the latter is nourished by the challenges that its own extension implies.

Historically, psychoanalysis has resisted and sustained its ethic under the policy that establishes protocols for care in hospitals. How can one react to the setting of a policy applying the medical-hygienic-pedagogical discourse that ever more overbearingly establishes manuals of diagnoses and procedures on which to base the work of professionals in healthcare institutions?

We shall conclude this brief account-that certainly contains some gaps, but whose objective was for us to investigate the way in which psychotherapy practices were slowly but surely inserted into hospitals in Brazil- 
with two situations from today's reality. We will exemplify this by describing the account of an experience which has taken place in recent years, woven in a university hospital in the state of Pará, in the north of the country, which has psychoanalysis as its theoretical base, and notes based on the experience which has taken place in the Psychology Service at the Liver Transplant and Surgery Discipline of the Hospital das Clínicas of the Medical School of the University of São Paulo [31].

\section{Creating Listening Mechanisms}

Sustaining the institutional clinic in the context of a study linked with clinical practice in the Developmental Ambulatory Care of the Bettina Ferro de Souza University Hospital (HUBFS) in Belém, in the state of Pará, we sought to transmit to the professionals on the team the effects of listening to the subject in a sensitive way. The Ambulatory cares for children with autism, serious neurological syndromes, learning difficulties, hyperactivity, among other diagnoses. What we saw at first is that apart from psychoanalysis there is no clinic, in the sense of listening to the children, since the psychological treatments being practiced follow the mode of working that we could identify as being in common with the mode that was being practiced in the 1970s, oriented toward clarifying, guiding and calming the anguish of the patients and family members. Clinical practice as we conceive it emphasizes the incidence of subjectivity, putting to use the mechanisms of psychoanalysis and relying on the existence of the subject who is present in the structure. We also acknowledge that this way of holding the clinic is only possible in an institution that includes professionals.

Taking literally Lacan's proposition that it is the supply that creates the demand for treatment, we opt for the possibility of clinically listening to the users of the service, which has not taken place without missteps, for we faced significant resistance. However, since the work of the psychoanalyst is a continual invention, we haven't been doing anything but inventing, without abandoning the theoretical-clinical and ethical foundations that guide our clinic, that cause us to take the speech of the subject in transference.

The Developmental Ambulatory Care of the HUBFS has been operating since 2002 and has a multidisciplinary team, including a psychologist, though he does not practice the clinic in the sense we highlighted above. The objective of this service is to diagnose and carry out ongoing psychological treatment of children up to 12 years of age with abnormal growth and development. The team's coordinator, a geneticist, and a neurologist who is the coordinator of the sector that cares for autistic children are professionals dedicated to working with the children and are open to the varied contributions of other areas, and requested that we do clinical work. This made it possible to carry out a dialogue between psychoanalysis and medicine, two forms of knowledge, in whose boundaries of knowledge the clinic can be understood in a complex way, rather than focalized based on causal and linear explanations. We opted for the construction of intervention strategies in the field of mental health for children who were autistic, psychotic and those bearing critical psychic suffering, at the same time treating and investigating issues involved in the subjective constitution of these subjects and their treatment.

The initial work was to identify treatment needs, listening to people in the waiting room and with physicians and other professionals, and this led us to the mechanism of the parents group. Starting with the idea that there is no way to treat children with autism, psychosis or any other psychopathology without the involvement of the parents in the treatment, due to their inclusion in the psychic structuring of the subject, we established the mechanism of listening to the parents, defined as treatment and not as a form of welcoming or guiding them. Since parents faced difficulties coming to the Hospital at a time other than when appointments were scheduled, and being attentive to the practices of the service offered at Developmental Ambulatory Care, we organized the group for listening to the parents around the times their children's medical appointments were scheduled. This was possible because of the working partnership with other professionals: occupational therapists, doctors, nurses, social workers and receptionists.

So we placed in the Ambulatory a group of psychologists with a psychoanalytic orientation to listen to the children, the parents and caregivers, without establishing any prior rule for how we would be working and primarily without ruling out any strategy that could serve as the motto for the work with the subject of desire. Keeping ourselves open to dialogue with the professionals and welcoming requests that they made to us, we began to see children individually which led to some requests for analysis.

Following the strict recommendation of Freud concerning the method, we adopted as a rule free association and free-floating attention. We believed that the conceptual foundations of Freudian-Lacanian psychoanalysis would allow us to respond to the issues raised by research with respect to the insertion of psychoanalysis into the 
hospital and into the public healthcare service as well as to think about how the position of the psychoanalyst on the team can promote a change involving the subject with their symptom. The early results surprised professionals who until then had considered the only effective treatment for these cases to be treatment oriented by cognitive behavioral psychology, compared to what was often dictated to be the "incompetence" of psychoanalysis.

This was fundamental also because we understood that without transference, both from the patients as well as the staff members with our work, the work would become stagnant. We saw that the praxis of the psychoanalyst at the institution is strengthened to the extent that the transference of the professionals on the team with our work is introduced. It is therefore necessary to work with the team. Hence the idea of interdisciplinarity, albeit controversial, since it can be interpreted based on the idea of totality, which is certainly not the focus of psychoanalysis.

The Psychology Service at the Liver Transplant and Surgery Discipline of the Clinics Hospital of the University of São Paulo School of Medicine, founded and coordinated by Moretto [31] in 1990, came to be recognized with a service comprised of psychoanalysts who developed research and work that indicate the viability of the psychoanalytic method in this context-since what defines the analytic nature of a practice is not the physical location where it takes place, but rather the theoretical, clinical and ethical standards that orient it-and are configured as a reference point for the link between psychoanalysis and the University, since the psychoanalysts develop their work simultaneously in the contexts of assistance, teaching, research and extension, concerning themselves with the education of students, with the supply of clinical care to the users of the hospital and with availability for interdisciplinary work.

\section{Discussion}

The "practice among many" or the "clinic among many" is an expanded psychoanalytical mechanism well-established in the public healthcare network, but it is also a challenge we must face in the hospital, given the lack of psychological care for children and their caregivers. We have observed that the work of the psychologist in the hospital is linked to the discourse of science and of pedagogy, limiting itself to apply educational procedures and guidance for some sectors of the clinic, which aims to do no more than calm, guide and advise so that the patient will comply with medical directives. Considering that the effect of this is to silence the symptom, excluding the subject of desire, the presence of the psychoanalyst with their offer to listen has made it possible to speak in transference, which includes the ethical dimension of the symptom, a pathway through which something of the subject appears.

So it is that the direction of treatment has also the challenge of following the way in which it is possible to develop research activities, and comes to be fashioned based on situations that arise within the institution, as well as exchanges and conversations with professionals about experiences and their needs. This represents the effort to develop the work in conjunction with the hospital team, while observing how we can solve service flow problems, referrals, etc. and listening to the needs of the professionals with their issues and difficulties in developing their work. This is a delicate activity that requires time and decision to be able to carry it out.

To the question we asked ourselves about whether there would be room for the psychoanalyst in an institution marked by medical discourse, which applies universal knowledge, guided by the certainty of its formulations, we answer with work. We have been undeterred by the difficulties and resistance we have faced, such as when professionals from the service disallow psychoanalysis as being unsuitable for treating autism, actually advising parents to take their children to be seen by a behavioral psychologist. To the contrary, we accepted the challenge of one of the doctors from the service to treat a child with serious autism, in order to prove the results of psychoanalytic treatment.

From the point of view of psychoanalysis, what the psychoanalyst's job is, whether it be in clinical work with subjects, whether it be working with the multidisciplinary team, is to support the importance of the unconscious dimension as a cornerstone of clinical work, which implies assistance to ensure the survival of psychoanalysis in the hospital.

If the position of the doctor before the patient is that of a person who possesses knowledge about an illness, which sooner or later will always turn out to be flawed to some extent, the psychological knowledge-which does not respond with a form of knowledge that is already established-is often the last hope.

Now that this practice has been moved into the hospital we have shown that in addition to the scientistic practices that throughout its history have been sustaining the way of doing psychotherapy in the hospital, there are 
ways of working based on the theoretical field of psychology itself which take into account each specific context of application, without any claim of constructing universal models. Psychoanalysis is one of them and it works by considering the specificity of relationships that are established in each institutional context to invent its praxis.

\section{References}

[1] Ismael, S.M.C. (2005) A inserção do psicólogo no contexto hospitalar [The Placement of the Psychologist in the Hospital Context]. In: Ismael, S.M.C., Ed., A prática psicológica e sua interface com as doenças [Psychological Practice and its Interface with Illness], Casa do Psicólogo, São Paulo, 17-37.

[2] Janssen, P. (2015) Psychoanalytic Therapy in the Hospital Setting. Routledge Library Ed., New York.

[3] Tasca, G.A., et al. (2015) What Clinicians Want: Findings from a Psychotherapy Practice Research Network Survey. Psychotherapy, 52, 1-11. http://www.apa.org/pubs/journals/features/pst-a0038252.pdf http://dx.doi.org/10.1037/a0038252

[4] Bruscato, W.L., Benedetti, C. and Lopes, S.R.A., Eds. (2004) A prática da psicologia hospitalar na Santa Casa de Misericórdia de São Paulo: novas páginas em uma antiga história [The Practice of Hospital Psychology at the Santa Casa de Misericórdia in São Paulo]. Casa do Psicólogo, São Paulo.

[5] (2005) Mathilde Neder. Psicologia: Ciência e Profissão [Online] [Psychology: Science and Profession], 25, 332-332. http://www.scielo.br/scielo.php?script=sci_arttext\&pid=S1414-98932005000200013 http://dx.doi.org/10.1590/S1414-98932005000200013

[6] Moretto, M.L.T. and Priszkulnik, L. (2014) Sobre a inserção e o lugar do psicanalista na equipe de saúde [About Insertion and the Place of the Analyst in the Health Team]. Tempo Psicanalítico [Psychoanalytic Time], 46, 287-298.

[7] Figueiredo, A.C. (1997) Vastas confusões e atendimentos imperfeitos [Massive Misunderstandings and Imperfect Care]. Relume Dumará, Rio de Janeiro.

[8] Sebastiani, R.W. (2000) Histórico e evolução da Psicologia da Saúde numa perspectiva latino-americana [History and Evolution of the Psychology of Health in a Latin American Perspective]. In: Angerami-Camon, V.A., Ed., Psicologia da Saúde-Um novo significado para a prática clínica [Psychology of Health-A New Meaning for Clinical Practice], Pioneira, São Paulo, 201-222. http://www.scielo.br/pdf/pcp/v24n1/v24n1a04

[9] Speroni, A.V. (2006) O lugar da psicologia no hospital geral [The Place of Psychology in the General Hospital]. Revista da Sociedade Brasileira de Psicologia Hospitalar [Journal of the Brazilian Society of Hospital Psychology], 9, 83-97. http://pepsic.bvsalud.org/scielo.php?script=sci arttext\&pid=S1516-08582006000200006\&lng=pt\&nrm=iso

[10] Eksterman, A. (1992) Medicina Psicossomática no Brasil (Psychosomatic Medicine in Brazil). In: Mello Filho, J., Ed., Psicossomática hoje [Psychosomatics Today], Artes Médicas Sul, Porto Alegre, 28-34.

[11] Alberti, S. and Almeida, C.P. (2005) Relatos sobre o nascimento de uma prática: psicanálise em hospital geral [Accounts of the Birth of a Practice: Psychoanalysis in a General Hospital]. In: Lima, M.M.L. and Altoé, S., Eds., Psicanálise, clínica e instituição [Psychoanalysis, Clinic and Institution], Rios Ambiciosos, Rio de Janeiro, 55-71.

[12] Caplan, G. (1964) Principles of Preventive Psychiatry. Basic Books, New York.

[13] Loreau, R. (1970). L'analyse institutionnelle [Institutional Analysis]. Eds. Minuit, Paris.

[14] Balint, M. (1957) The Doctor, His Patient and the Illness. Churchill Livingstone, London.

[15] Moreno, J. L. (1973) Psicoterapia de grupo e psicodrama [Group Psychotherapy and Psychodrama]. Mestre Jou, São Paulo.

[16] Bettelheim, B. (1967) The Empty Fortress: Infantile Autism and the Birth of the Self. The Free Press, New York.

[17] Mannoni, M. (1967) L'enfant, sa "maladie” et les autres [The Child, His Illness and the Others]. Seuil, Paris.

[18] Raimbault, G. (1975) L'enfant et la mort: des enfants malades parlent de la mort, problèmes de la clinique du deuil [The Child and Death: Sick Children Talk about Death, Problems in the Clinic of Mourning]. Privat, Coll. Éducateurs, Toulouse.

[19] Foucault, M. (1963) Naissance de la clinique. Une archéologie du regard médical [The Birth of the Clinic: An Archaeology of Medical Perception]. P.U.F., Paris.

[20] Deleule, D. (1971) Le philosophe et le psychologue [The Philosopher and the Psychologist]. Revue Philosophique, [Philosophical Review], 161, 19-28.

[21] Canguilhem, G. (1966) Le normal et le pathologique [The Normal and the Pathological]. P.U.F., Paris.

[22] Machado, R.C.M., Loureiro, A., Luz, R. and Muricy, K. (1978) Danação da Norma. Medicina social e a constituição da psiquiatria no Brasil [Damnation of the Norm. Social Medicine and the Constitution of Psychiatry in Brazil]. Graal, Rio de Janeiro. 
[23] Costa, J.F. (1979) Ordem médica e norma familiar [The Medical Order and Family Norms]. Graal, Rio de Janeiro, 1983.

[24] Santos, F.A.F., Valentim, J.H. and Mattos, P. (Not Dated) A Psicologia em Hospital Geral [Psychology in a General Hospital]. Text Published by the Antonio Pedro University Hospital of the Universidade Federal Fluminense [Fluminense Federal University], Fluminense. http://www.uff.br/spac/arquivos/A\%20Psicologia\%20no\%20Hospital\%20Geral.pdf

[25] Mendes, E.V., Ed. (1994) Planejamento e Programação Local da Vigilância da Saúde no Distrito Sanitário. Série Desenvolvimento de Serviços de Saúde 13 [Local Planning and Programming of Health Surveillance in the Health District. Development of Healthcare Services Series 13]. Organização Pan-Americana da Saúde [Pan-American Health Organization], Brasília.

[26] Dimenstein, M.D.B. (1998) O psicólogo nas Unidades Básicas de Saúde: desafios para a formação e atuação profissionais [Psychologists in Public Health Services: Challenges to Professional Training and Practice]. Estudos de Psicologia (Natal) [Studies of Psychology (Natal)], 3, 53-81.

http://www.scielo.br/scielo.php?script=sci_arttext\&pid=S1413-294X1998000100004\&lng=en\&tlng=pt

[27] De Almeida, E.C. (2000) O psicólogo no hospital geral [The Psychologist in the General Hospital]. Psicologia: Ciência e profissão [Psychology: Science and Profession], 20, 24-27. http://dx.doi.org/10.1590/S1414-98932000000300005

[28] Costa, J.F. (1989) Psicanálise e Contexto Cultural. Imaginário Psicanalítico, Grupos e Psicoterapias. 2. ed. [Psychoanalysis and Cultural Context. Psychoanalytic Imagination, Groups and Psychotherapies]. 2nd Edition, Cam- pus, Rio de Janeiro.

[29] Martín-Baró, I. (1984) Guerra y salud mental. Conferencia pronunciada en San Salvador el 22 de Junio de 1984, en la inauguración de la "I Jornada de la Salud Mental" y publicada en "Estudios Centroamericanos", 1984, no 429/430 [War and Mental Health. Talk Given in San Salvador on June 22, 1984 at the Opening of the "First Conference on Mental Health" and Published in "Central American Studies” 1984, No. 429/430]. 503-514. http://www.papelesdelpsicologo.es/vernumero.asp?id=585

[30] Calazans, R. (2005) Psicanálise e política [Psychoanalysis and Politics]. Revista de Psicologia Política [Journal of Political Psychology], 8, 17-30.

http://pepsic.bvsalud.org/scielo.php?script=sci_arttext\&pid=S1519-549X2008000100003\&lng=pt\&nrm=iso

[31] Moretto, M.L.T. (2006) O psicanalista num programa de transplante de fígado: a experiência do "outro em si” [The Psychoanalyst in a Liver Transplant Program: The Experience of the "Other in Himself”]. Tese (Doutorado) [Dissertation (Doctoral)], Instituto de Psicologia da Universidade de São Paulo [Institute of Psychology, University of São Paulo], São Paulo.

[32] Lacerda, F. (2013) Psicologia política Latino-Americana [Latin American Political Psychology]. Revista de Psicologia Política [Journal of Political Psychology], 13, 559-573. http://pepsic.bvsalud.org/scielo.php?script=sci_arttext\&pid=S1519-549X2013000300010\&lng=pt\&tlng=pt

[33] Tonetto, A.M. and Gomes, W.B. (2005) Prática psicológica em hospitais: demandas e intervenções [Psychological Practice in Hospitals: Demands and Interventions]. Psico, 36, 283-291. http://www.ufrgs.br/museupsi/lafec/27.pdf

[34] Borch, C. (2012) The Politics of Crowds. Cambridge University Press, Cambridge. http://dx.doi.org/10.1017/CBO9780511842160

[35] Freud, S. (1921/1999) Massenpsychologie und Ich-Analyse [Group Psychology and the Analysis of the Ego]. In: Gesammelte Werke [Collected Works], Vol. 13, Fischer Taschenbuch Verlag, Frankfurt am main, 73-161.

[36] Slochower, H. (1970) Mythopoiesis. Wayne State University Press, Detroit.

[37] Alberti, S., Erlich, H., Mocarzel, P., Monteiro, P., Prata, D. and Reis, L.E.G. (2008) Encaminhamentos e dispersão. Questões para a psicanálise no hospital [Directions and Dispersion. Questions for Psychoanalysis in the Hospital]. Estudos e pesquisa em psicologia [Studies and Research in Psychology], 8, 42-57. http://www.revispsi.uerj.br/v8n1/artigos/pdf/v8n1a05.pdf

[38] Alberti, S. (2000) Psicanálise: a última flor da medicina [Psychoanalysis: The Last Flower of Medicine]. In: Alberti, S. and Elia, L., Eds., Clínica e pesquisa em psicanálise [Clinic and Research in Psychoanalysis], Rios Ambiciosos, Rio de Janeiro, 37-56.

[39] Dunker, C.I.L., Ramirez, H.H.A. and Assadi, T.C., Eds. (2011) Pele como litoral [Skin as Coastline]. Annablume, São Paulo.

[40] Moura, M.L. (Ed.) (1996) Psicanálise no hospital [Psychoanalysis in the Hospital]. Revinter, Rio de Janeiro.

[41] Nascimento, E.M.V. and Gonzales, R.C.F., Eds. (2010) A Clínica Psicanalítica: reflexões teóricas e incidências institucionais na contemporaneidade [The Psychoanalytic Clinic: Theoretical Reflections and Institutional Effects on Contemporaneity]. Ed. EDUFBA, Salvador. 
[42] Rinaldi, D. (2005) Clínica e Política: a direção do tratamento psicanalítico no campo da saúde mental [Clinic and Politics: The Direction of Psychoanalytic Treatment in the Field of Mental Health]. In: Altoé, S. and Lima, M.M., Eds., Psicanálise, clínica e instituição [Psychoanalysis, Clinic and Institution], Rios Ambiciosos, Rio de Janeiro, 87-106.

[43] Moretto, M.L.T. (2013) O que pode um analista no hospital? [What Can an Analyst Do in the Hospital?]. $4^{\mathrm{a}}$ edição [4th edition], Casa do Psicólogo, São Paulo.

[44] Mackie, B.S. (2016) Treating People with Psychosis in Institutions. Karnac, London.

[45] Lacan, J. (1966) La place de la psychanalyse dans la médecine [The Place of Psychoanalysis in Medicine]. Unpublished. http://www.valas.fr/J-Lacan-La-place-de-la-Psychanalyse-dans-la-Medecine, 166

[46] Freud, S. (1926/1999) Die Frage der Laienanalyse [The Question of Lay Analysis]. In: Gesammelte Werke [Collected Works], Vol. 14, Fischer Taschenbuch Verlag, Frankfurt am main, 208-286.

[47] Freud, S. (1927/1999) Nachwort zur "Frage der Laienanalyse” [Afterword to “Question of Lay Analysis”]. In: Gesammelte Werke [Collected Works], Vol. 14, Fischer Taschenbuch Verlag, Frankfurt am main, 287-296.

[48] Lacan, J. (1998) A Direção do Tratamento e os Princípios de seu poder [The Direction of the Treatment and the Principles of Its Power]. In: Escritos, L.J., [Writings], Jorge Zahar, Rio de Janeiro, Translated from French, First Published in 1958.

[49] Lacan, J. (1992) Seminário 17: O Avesso da Psicanálise (1969-1970) [Seminar 17, The Other Side of Psychoanalysis (1969-1970)]. Jorge Zahar, Rio de Janeiro.

\section{Submit or recommend next manuscript to SCIRP and we will provide best service for you:}

Accepting pre-submission inquiries through Email, Facebook, Linkedin, Twitter, etc A wide selection of journals (inclusive of 9 subjects, more than 200 journals)

Providing a 24-hour high-quality service

User-friendly online submission system

Fair and swift peer-review system

Efficient typesetting and proofreading procedure

Display of the result of downloads and visits, as well as the number of cited articles

Maximum dissemination of your research work

Submit your manuscript at: http://papersubmission.scirp.org/ 